\title{
Analysis of Academic Interpersonal Communication Factors in the Covid-19 Pandemic Period of Buddhist College Students
}

\author{
Hesti Sadtyadi \\ Santi Paramita \\ Department of Dharmacarya, Dharmaduta, \\ Buddhist Religious Education, \\ Raden Wijaya State Buddhist College, \\ Wonogiri, Indonesia
}

DOI: https://doi.org/10.36941/jesr-2022-0013

\section{Abstract}

This study aims to determine the factors influencing interpersonal communication of Buddhist College students, in the online learning process during the covid-19 pandemic, and (2) know the indicators that affect the student's interpersonal communication factors. This study uses a mixed-method. Qualitative methods are used to describe the data descriptively, while quantitative methods are used in factor analysis. Respectively, the most influential factor on interpersonal communication is the motivation in communicating in the academic field, with a score of 0.81 , followed by self-confidence with a score of 0.67 , and lastly, openness, with a score of o.67. Each factor is composed of four indicators as follows. For example, confidence is composed of belief, a sense of responsibility, objectivity, and rationality. The strongest indicator of the self-confidence factor is the belief in one's abilities. Meanwhile, achievement motivation factors are mostly composed of such indicators as a willingness to learn, adaptability, the desire to excel, and the existence of communication efforts. The indicator of the strongest motivational factors is achievement motivation. In addition, the openness factor is composed of indicators of equality, environmental interaction, mutual trust, and values. The strongest indicator of the openness factor is the value of interpersonal communication, especially in online learning processes.

Keywords: interpersonal communication, self-confidence, motivation, openness

\section{Introduction}

Developments and changes in today's environment, as severely affected by the Covid-19 pandemic, impacted several life aspects including the socio-economic community. Many people have lost their jobs as their main income. Their psychological-social life experiences a lot of disturbances, worry, and anxiety as the result of the covid-19 pandemic which provides uncertainty in people's lives. This, also, has a huge impact on the educational process. For example, because of online learning processes, there are new demands that previously did not even exist, which become new problems, such as the increasing need for an internet network and its supporting equipment. Before the pandemic everything could be fulfilled more simply, yet, todays' changes emerge as the new utilities needed to support the learning process, especially within the family members. 
The Covid-19 pandemic has changed all aspects of education, including higher education. Fundamental changes occurred specifically in the process of student-teacher meetings. The previous face-to-face teaching and learning process has changed to the online learning process (AlmonacidFierro et al., 2021), (Pavan Kumar, 2021). The changes require all stakeholders to adapt to the situation by making the learning process sufficiently conducted through media and information technology (Bismala \& Manurung, 2021), (Saripudin et al., 2020). The process of adaptation in the learning process in the pandemic era will also have an impact on less-effective academic affairs, or even the possibility of misunderstandings in academic contexts. This is also known as academic anxiety. This anxiety can arise due to conditions caused by feelings of excessive anxiety as the result of various academic tasks (Anugrah et al., 2021).

During the learning process in the covid-19 pandemic, there are obstacles found to affect the continuity and sustainability of the learning process. For example, the online learning process may create new challenges emerging from the family environment, students, infrastructure, and educators (Wahyono et al., 2020). The learning process at the higher education level with its learning model and independence makes it important to do an in-depth study, how its sustainability can be effective and efficient. It is also necessary to see how the role of the students and lecturers in maintaining and creating a better learning atmosphere, or how to communicate well.

The management of higher education needs to pay attention to the potential of students, considered as the millennial students, as they are the generation born in the digital era. This is in line with the pandemic condition, which requires all stakeholders to do everything online. In one part of online or virtual learning, through well-guided steps, it can help students to increase their earning motivation, as stated by Menon (Shanmugam \& Balakrishnan, 2019). The current generation, known as Generation Z relies heavily on the state of technology (Samala et al., 2020), (Hadion Wijoyo et al., 2020). Many exemplified how this generation uses online media, showing that they are very attached to smartphones or online media (Firamadhina \& Krisnani, 2021).

The learning process for the gen- $Z$ has special characteristics to consider, including the aforementioned criteria, in which this generation tends to use online media especially those providing entertainment content, such as Instagram, You tube, and Tik Tok. It should also be understood that the amount of time they spent accessing the videos is relatively shorter than that of the previous generation (Hadion Wijoyo et al., 2020). Based on these characteristics, it is also necessary to pay attention to how to use learning media in the online learning process appropriately (Sadtyadi, 2021). Thus, it indicates the complexity of the problems in online learning does exist, especially on how to maintain good communication, to be in line with the real situation.

In addition to these problems, another thing to consider is the family background, for example, students are living in areas where the internet is accessible, while others are living in areas where the internet is not accessible (Basar, 2021). Regional or geographical differences can also create disparities in the internet service quality, requiring students to make various adjustments during the learning process, such as looking for places or locations with good internet reception. Looking for appropriate internet access coverage to ensure maximize the learning process is an important part to consider. Problems related to a location with internet coverage are factors that cannot normally be identified by the lecturers. However, to ensure that the student-lecture communication can take place properly, those problems do need to be aware of.

Internet service interference can be a main problem in the online learning process, not to mention the problems in readiness of the students or the lecturers to take part in the online learning process (Hidayat et al., 2020). Meanwhile, other additional problems may occur, such as the socioeconomic conditions of the students, especially in providing facilities to support the learning process. While most students may have sufficient equipment to support the learning process like mobile phones (Android), other unfortunate students will still find it difficult to purchase laptops or notebooks. This shows that the students need motivation (Agustina \& Kurniawan, 2020) or support to keep them enthusiastic to follow online learning despite the insufficient facilities. It is expected that the students can communicate anything related to their problems, can adapt to the online 
learning process, and be effortful during the online learning process.

The implementation of the learning process relies heavily on two-way communication, between the students and the lecturer. Communication is a connecting part to accept as well as to find solutions for online learning problems that may exist especially during the covid-19 pandemic. Students, as learners, play a role in preparing themselves to follow the learning and evaluation processes held by the institution. In addition, the interpersonal communication of the students in academic activities will have an impact on students' achievement (Abubakar, 2015), (DeVito, 2013). Interpersonal communication becomes an important part and foundation in achieving the success of the learning process. Through good communication, it will be easy to understand the materials being taught by the lecturers and to do the assignments from the lecturer. Siburian (Ramadanty \& Martinus, 2016) stated that effective interpersonal communication, good academic culture, and high achievement motivation will take part in improving students' interpersonal communication.

In terms of students' communication in the learning process, it is related to the commitment of the students themselves as internal support to maintain the quality learning process to produce successful learning. The commitment that arises from the students, as part of the attitude shows how the students are related to the institution or faculty members. The students' commitment is expected to be a developing and sustainable support system to help the students achieve their learning success.

The importance of open communication and honesty is important part of today's learning process. Problems that occur in the learning process must be communicated, to prevent a bigger impact on the stakeholders. The lecturers, as the educators, must be able to see facts as well as to find the underlying motivation of the students in participating in the learning process. The existence of an academic culture that takes place in the era of the covid-19 pandemic must also ensure the continuity of good communication. As the result, it is necessary to reveal the factors that affect the interpersonal communication of Buddhist College students, in the online learning process, especially during the covid-19 pandemic. Also, it is no less important to find the indicators that affect the student's interpersonal communication factors.

\subsection{Academic Interpersonal Communication}

A well-developed academic communication process can produce a conducive academic atmosphere to establish a communicative culture, which supports academic success in a higher education environment. Communication is a key part of the management process. Communication is part of behavior in carrying out academic actions (Abubakar, 2015), (Gabatino \& Afalla, 2021) to be able to establish a conducive academic culture.

The communication process among students and lecturers or faculty members within the educational environment is an important and influential part of establishing a harmonious atmosphere in the learning process. In the process of communication, as shown by the language classes, there are several overviews of how communication in the classroom happens, such as, Lee and Hsieh (Mulyono \& Saskia, 2021), who provided an overview of the confidence factor as one of the strong variables that influence communication. Meanwhile, Khajavy et al. (Mulyono \& Saskia, 2021), showed variables that play an important role in communication in the learning process, such as selfconfidence, motivation, and anxiety in delivery. MacIntyre, (Weda et al., 2021), regarding the communication model (WTC) states that there are layers related to the model of communication willingness. The first layer is the behavior in communicating, or, the intention to communicate, the second layer is the desire or willingness to communicate, and the third layer is the motivational, affective and cognitive context, or, the individual's social context.

Interpersonal communication is the process of delivering information to others either directly or indirectly (Barseli et al., 2019), (Gunawati et al., 2006), (Pearson et al., 2011) Some of the most important interpersonal communication skills are demonstrated by the following factors: attention, cultural sensitivity, focus, openness, metacommunication, or the ability to talk about conversation, togetherness, flexibility, expressiveness, empathy, supportiveness, equality and interaction 
management (DeVito, 2013). Interpersonal communication for students is very important especially in the pursuit of academic success. At the same time, interpersonal communication affects student success, in which through interpersonal communication, students' efforts to fulfill assignments can be more effective (Oktary et al., 2019). Furthermore, in this case, interpersonal communication is influenced by self-confidence, achievement motivation, and openness.

Self-confidence is an important part of interpersonal communication (DeVito, 2013). Confidence in communicating is a sense of confidence in the form of the ability to convey messages clearly without interference. In his opinion, Wilis states that self-confidence is a person's belief in solving problems and ability to create pleasant conditions (Anggeraini \& Farozin, 2019). Confidence can be influenced by the level of confidence in abilities, responsibility, objective, rationality, and realism (Sari, 2018).

Interpersonal communication can also be encouraged as the basis of motivation. Motivation is a personal feeling or situation as a driving force that comes from within a person (Akomolafe et al., 2013)(Shaleh, 2016). Motivation may vary among individuals. Also, motivation in the learning process is more about the motivation regarding the interaction between the teachers and students, (Shanmugam \& Balakrishnan, 2019)(Wichanpricha, 2021), or in a college situation and context, between lecturers and students in their learning environment. Furthermore, motivation is the foundation to achieve certain goals. In the learning process, the media can be a part of intrinsic motivation (Navarro et al., 2020). Also, the use of IT equipment can be another supporting part in improving students' competence. In the learning process, achievement motivation becomes an important part more specifically in terms of encouraging the students in the learning process during the covid-19 pandemic. This kind of motivation has similarities, especially in terms of the motivation to use IT as a learning tool in supporting the successful learning process at the Buddhist College. The motivation itself is the achievement motivation, especially to help the students develop the interpersonal communication ability in the learning process through online media. McClelland (Siburian, 2013) stated that there are four standard aspects of achievement motivation, namely 1) risktaking 2) immediate feedback 3) achievement satisfaction, 4) loving the job. In terms of students' motivation, the standards in achievement motivation include 1) willingness to participate in online learning, 2) being able to adapt to online learning, 3) encouragement to succeed in learning, and 4) strong effort and enjoyment during the learning process.

In realizing good interpersonal communication within the academic process in the era of the covid19 pandemic, openness is needed, which is realized by equality, selflessness, harmlessness, and mutual trust (Hidayat, 2012). The communication between the learning process can be effective, yet it requires students' and teachers' openness, environmental interaction, and equality among them (Rina et al., 2019). Meanwhile, in developing interpersonal communication through openness, in this case, it is necessary to have equality, values, environmental interactions, and trust between the students and the teachers.

\section{Research Method}

\section{$2.1 \quad$ Research Designs}

This study uses a mixed-method; qualitative and quantitative methods. Qualitative methods are used to describe the data in a descriptive way, while quantitative methods are used in factor analysis. The data collection process for the two methods was carried out simultaneously (Creswell, 2014). The techniques, strategies, and analysis in data collection were also applied. The validity test was conducted by using a descriptive validity test, using Aiken's V analysis (Aiken, 1985). In addition, construct validity and reliability tests were also carried out. To answer the research questions, related and supporting theories are elaborated, especially about: (1) What are the factors that influence the interpersonal communication of Buddhist College students in the online learning process during the covid-19 pandemic? (2). What are the indicators that influence the factors in students' interpersonal communication? 


\subsection{Research Samples}

This research was conducted at the Buddhist College in Indonesia. The research was conducted at three Buddhist Colleges in Sumatra, one college in Banten, and one college in Central Java, especially on students of the Buddhist Religion Study Program. The number of samples used was 121 students of all five colleges as aforementioned.

\subsection{Data Collection and Analysis}

The data were collected through a survey using a questionnaire, which is integrated with Google Forms. Data analysis was carried out by descriptive qualitative analysis, and quantitative analysis. Qualitative data analysis is delivered through descriptive analysis, while quantitative analysis is explained through exploratory factor analysis (EFA), confirmatory analysis (CFA), and Structure Equation Model (SEM). This analysis is used to answer the question about the factors that affect student interpersonal communication in the Covid-19 pandemic era. The value of the loading factor as a determinant that the indicator is accepted is 0.5. Meanwhile, in determining the fit of the model, the researcher used RMSEA, and Chi-Square (Wijanto, 2008)(Ghozali, 20o8). The programs used in the analysis are SPSS and Lisrel programs.

\section{Results and Analysis of the Study}

\subsection{Qualitative Analysis on Students' Interpersonal Communication}

The results of the study showed that students' academic communication during the covid-19 pandemic was carried out using online media, or through electronic devices as a medium of interaction. Academic communication is carried out both in the learning process, and academic consultation activities. The implementation of the academic communication process can be explained from the factors of student self-confidence, self-motivation, and openness from students and lecturers. Through these factors, it provides further explanations on how students' academic communication can take place at Buddhist College, and how students' academic communication explains students' academic problems, such as student self-confidence, laziness that appeared during the COVID-19 pandemic, or other disturbances, also the relationship between lecturers and students. Each aspect will be explained in further analysis.

\subsection{Students' Self Confidence}

In terms of students' self-confidence, during the covid-19 pandemic and online learning process shows a great result through the survey, in which, around the percentage of $81 \%$, students are feeling very confident in their ability to learn online. Meanwhile, the confidence aspect in communication shows that $77.7 \%$ of students have a very good responsibility in academic communication. Confidence, based on their objectivity in academic communication, is at $74.4 \%$, which is considered very good, while rationality is at $76 \%$ which is very good as well. However, there are also results of the survey answers showing students with a lack of self-confidence, with an average range of $3 \%$ for each indicator, the survey answers showing the students with average self-confidence were ranging from $6 \%$ to $7 \%$. This further illustrates that in online learning, it is necessary to increase student confidence in the process of all academic interactions. Students' self-confidence in conducting academic communication interactions in the learning process can also be affected by the internet network quality. Statistically, almost $23.7 \%$ of respondents stated that they underwent internet reception disturbances during the communication process. 


\subsection{Students' Achievement Motivation}

Students' achievement motivation in online academic communication during the covid-19 pandemic also illustrates the results of the survey that the willingness to carry out academic communication is $74.38 \%$, which is considered very good, while the ability to adapt is $61.98 \%$ which is considered very good. Meanwhile, the encouragement to gain achievement is at $83.47 \%$, considered very good, and lastly, the effort in doing academic communication is $66.12 \%$, considered very good as well. From the data, it is found that the motivation is very good, as shown by the percentage of the encouragement to gain achievement factor. On the other hand, factors like the willingness to communicate, the willingness to adapt, and the effort have resulted in a relatively smaller percentage, ranging from $3 \%$ to $4 \%$. This shows that in terms of motivation, there are still several students who need to be further encouraged or motivated so they will have good abilities in terms of academic interpersonal communication quality.

\subsection{Openness}

The results of the survey in terms of openness to interact in interpersonal communication in the academic context during the covid-19 pandemic through online learning show that equality in supporting the openness of academic communication is at the score of $71.9 \%$ which is considered very good; openness will have a very good value with the score of $66.12 \%$; openness to doing environmental interaction with the score of $70.25 \%$ which is very good, and openness in academic communication based on mutual trust with the score of $71.9 \%$ which is considered very good. Meanwhile, in terms of equality, having environmental values and interactions, survey results are relatively achieving lower percentage, ranging from $2.5 \%$ to $4.13 \%$. This gives an illustration that there is still unwillingness toward openness in academic communication in the online learning process. Finally, there is $2 \%$ of the respondents, who did not respond to problem-solving in the online learning process, through communication, including to their colleagues. This may get worse due to the existence of students' environmental conditions, especially the internet network. Statistically, there is $10.9 \%$ of the respondents need to find a location where the internet reception quality is better. Finally, there is $10.9 \%$ of the respondents said that they always try to adjust to the environment to ensure the stability of academic communication in online learning.

\subsection{Quantitative Analysis using Exploratory Factor Analysis}

The results of this study were analyzed using Exploratory Factor Analysis (EFA), as shown in Table 1, that the KMO is 0.887 , with a significance of Bartlett's Test of Sphericity, of o.oo, which is significant, indicating that the model can be used for further analysis. KMO o.8 is called meritorious (Hair et al., 2006).

Table 1: KMO Calculation Results

KMO and Bartlett's Test

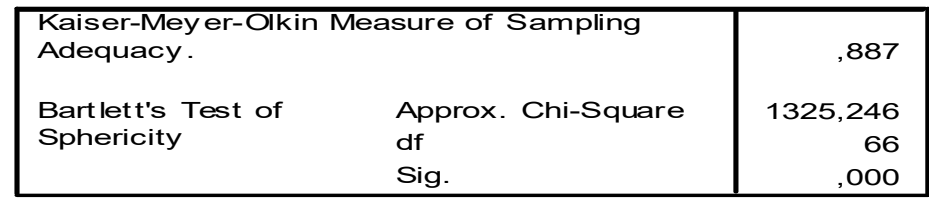

Based on the analysis using Exploratory Factor Analysis, as shown Table 2, resulting in anti-image for each component is greater than 0.5 , which further indicates that each component indicator in the communication instrument is valid and can be used for further analysis. 
Table 2 : Anti Image Correlation

\begin{tabular}{|l|l|r|}
\hline \multirow{4}{*}{ Anti-image Correlation } & Abilities &, $849(\mathrm{a})$ \\
\cline { 2 - 3 } & Responsib &, $860(\mathrm{a})$ \\
\cline { 2 - 3 } & Objective &, $931(\mathrm{a})$ \\
\hline & Rational &, $806(\mathrm{a})$ \\
\hline & Perform &, $904(\mathrm{a})$ \\
\hline Willing &, $920(\mathrm{a})$ \\
\hline & Effort &, $921(\mathrm{a})$ \\
\hline & Adaptab &, $881(\mathrm{a})$ \\
\hline & Equality &, $897(\mathrm{a})$ \\
\hline & Trust &, $900(\mathrm{a})$ \\
\hline & Interaction &, $839(\mathrm{a})$ \\
\hline
\end{tabular}

Table 3: Loading Factor with Exploratory Factor Analysis

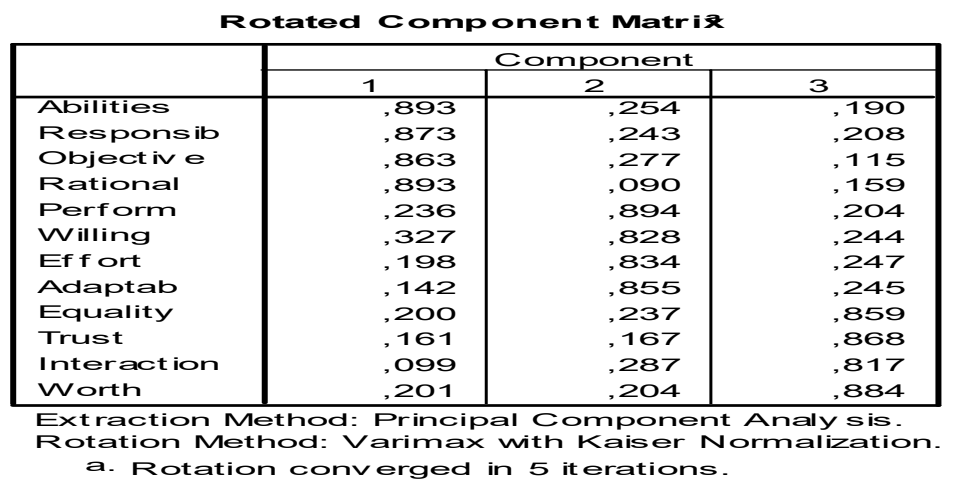

By using the loading factors through SPSS, as shown in Table 3, it is shown that the loading factor of each indicator of interpersonal communication variables is bigger than 0,5 , meaning that each dominating indicator is composing the components.

\subsection{Confirmatory Factor Analysis (CFA)}

By using the CFA analysis with the Lisrel program, as shown in Figure 1, it is found that the model has a model fit, as seen from $x^{2}=57.22(P=0.32533)$, the value of $x^{2}>0.05$, which indicates that the predicted input matrix compared to the actual input is not statistically different (Hair et al., 2006), (Wijanto, 2008), (Ghozali, 2008) said that the model was declared fit if, GFI > 0.9 and RMSEA < 0.08. As the result of the calculation, a fit model is generated with GFI $=0.93$, and RMSEA $=0.032$.

In terms of reliability, the value of the coefficient (delta), can be used as the value of reliability, by performing calculations ( $1-\delta$ (delta)), showing the value of reliability, this can also be judged by the $\mathrm{R}$ Square error variance. It also shows that the coefficients (delta) are all significant, as shown by the $\mathrm{t}$-test, $\mathrm{t}$-count which is greater than t-table. This also indicates that each instrument is reliable. Similarly, from the calculation of reliability using SPSS, the resulting value of 0.923 indicates that the instrument used is reliable.

Based on the result of factor analysis by using lisrel, it shows that each indicator of the factors, as well as the factors of the variables, with a t-test, which shows $t$ count $>t$ table, resulted that each factor composes indicator and each variable constituent factors is valid. This means that the 
interpersonal communication variables of the students of Buddhist higher education are deeply influenced by three components, namely self-confidence, motivation, and openness. Similarly, each component is influenced by four indicators respectively.

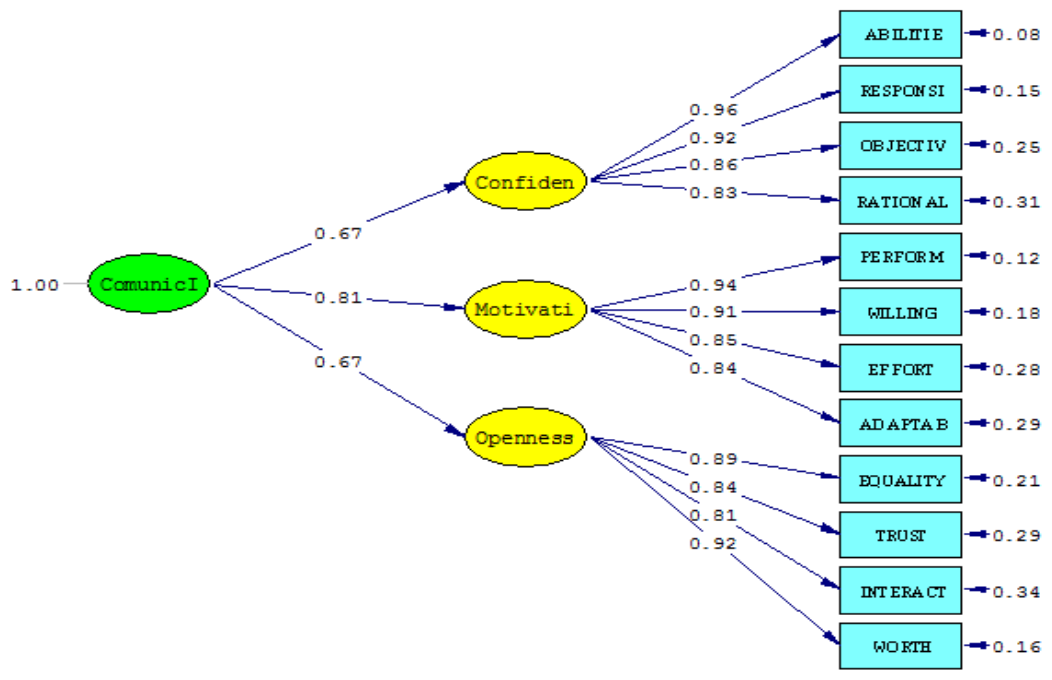

Chi-Square=57.22, df $=51, \mathrm{P}$-value $=0.25533, \mathrm{RMSEA}=0.032$

Figure 1: The Result of Analysis using CFA

Respectively, the most influential components on interpersonal communication are achievement motivation in academic communication, with a score of 0.81 , and self-confidence with a score of 0.67 , and openness with a score of 0.67 . Confidence is composed of such indicators as the ability to communicate, a sense of responsibility, objectivity, and rationality. In terms of the self-confidence factor, the strongest indicator is the belief in one's ability through academic communication in online learning. Meanwhile, the communication factor is composed of four characteristics, namely achievement motivation, willingness to learn online, the ability to adapt to the learning process, the encouragement to excel academically, and efforts to establish good communication in the online learning process. The indicator of the strongest achievement motivation factor is the encouragement to excel. In addition, the openness factor is composed of four indicators such as equality in communication, environmental interaction, and mutual trust and values in communication, especially in conducting online learning during the covid-19 pandemic. The strongest indicator of openness is the values about interpersonal communication, more specifically, in online learning processes.

\section{Discussion}

The results of this study indicate that the interpersonal communication of Buddhist College students during the covid-19 pandemic, especially during online learning processes, can be explained by several influencing factors. Those influencing factors are motivation, self-confidence, and openness. Each factor can be described in terms of the indicators that affect it. This shows that there are similarities with the opinion of Khajavy et al. [19]. Variables that have an important role in communication in the learning process are self-confidence, motivation, and anxiety in delivery. In terms of openness, this is in line with the opinion of DeVito, (DeVito, 2013), who stated that one of 
the factors that influence interpersonal communication is openness. The openness referred to in the findings of this study, in the form of openness inequality between lecturers and students, value in communication, environmental interaction, and mutual trust.

Motivation factors play the most important roles in interpersonal communication. This is in line with McClelland's opinion (Siburian, 2013), (Ridha, 2020). It was stated that there are four standard aspects of achievement motivation, namely 1) risk-taking 2) immediate feedback, 3) achievement satisfaction, and 4) loving the job. The results of the research are in line with this opinion, stating that achievement motivation in interpersonal communication in the academic field is in the form of willingness to learn online, the ability to adapt to the learning process, encouragement to gain academic achievement, and good communication ability when participating in the online learning process. The motivational factor influencing academic interpersonal communication is the most powerful. The motivation for achievement becomes the catalyst in achieving those goals. Encouragement will emerge continuously, with various challenges, and the ability to accept feedback as part of improvement. Achievement motivation can be interpreted as part of the driving force of the individual to behave (Sugiyono, 2003).

Openness in academic communication is an important part of self-disclosure (DeVito, 2013). The sense of openness will make it easier to understand what is learned and practiced. Equality in communication, environmental and social interaction, and mutual trust and value become an important part of the success of academic interpersonal communication.

Interpersonal communication is an important part of helping someone to be successful in achieving goals. This is by the opinion of Morreale \& Pearson (DeVito, 2013). The ability in interpersonal communication will make it easier to describe and implement the target steps in the learning process. Finally, the quality of interpersonal competence and supporting factors that influence interpersonal competence can help students to improve their academic achievement.

\section{Conclusion}

Interpersonal communication of Buddhist higher education students is influenced by three components or factors, namely self-confidence, motivation, and openness. Each of the supporting factors of academic interpersonal communication is elaborated through four constituent indicators. Confidence is composed of such indicators as the ability to communicate, a sense of responsibility, objectivity, and rationality. Achievement motivation, composed of the willingness to learn online, the ability to adapt to the learning process, the desire to gain academic achievement, and the existence of communication in participating in the online learning process. Meanwhile, the openness factors are indicators of equality in communication, environmental interaction, mutual trust, and values in communication especially in carrying out online learning during the covid-19 pandemic.

Self-confidence, motivation, and openness factors, as in line with their indicators, have a very important role and influence in academic communication. The existence of good scores from each indicator and factor can increase academic success at the Buddhist College.

\section{Acknowledgment}

This research was under the acknowledgment and help of the State Buddhist College of Raden Wijaya Wonogiri, Central Java. The researcher hereby thanks all parties and stakeholders involved in providing support and encouragement upon the completion of the research and the writing of the article.

\section{References}

Abubakar, F. (2015). Pengaruh Komunikasi Interpersonal antara Dosen dan Mahasiswa Terhadap Motivasi Belajar dan Prestasi Akademik Mahasiswa. Jurnal Pekommas, 18(1), 53-62. https://www.neliti.com/publications/222386/ 
Agustina, M. T., \& Kurniawan, D. A. (2020). Motivasi Belajar Mahasiswa di Masa Pandemi Covid-19. Jurnal Psikologi Perseptual, 5(2), 120. https://doi.org/10.24176/perseptual.v5i2.5168

Aiken, L. R. (1985). Three Coefficients for Analyzing the Reliability and Validity of Ratings. Educational and Psychological Measurement. https://doi.org/https://doi.org/10.1177/o013164485451012

Akomolafe, M. J., Ogunmakin, A. O., \& Fasooto, G. M. (2013). The Role of Academic Self-Efficacy, Academic Motivation and Academic Self-Concept in Predicting Secondary School Students' Academic Performance. Journal of Educational and Social Research, 3(May), 335-342. https://doi.org/10.5901/jesr.2013.v3n2p335

Almonacid-Fierro, A., Vargas-Vitoria, R., De Carvalho, R. S., \& Fierro, M. A. (2021). Impact on teaching in times of COVID-19 pandemic: A qualitative study. International Journal of Evaluation and Research in Education, 10(2), 432-440. https://doi.org/10.11591/ijere.v10i2.21129

Anggeraini, D., \& Farozin, M. (2019). Interpersonal Communication Skills and Self Confidence of Secondary School Students: Findings and Interventions. KnE Social Sciences, 2019, $140-145$. https://doi.org/10.18502/kss.v3i17.4633

Anugrah, F. S., Nur, R. S., Kristiawan, M., \& Yuliarsih, F. (2021). Self Modeling Mengatasi Kecemasan Mahasiswa Dalam Menghadapi Dosen Pembimbing. JOEAI (Journal of Education and Instruction), 4(1), $108-114$. http://dspace.ucuenca.edu.ec/bitstream/123456789/35612/1/Trabajo de Titulacion.pdf\%oAhttps://educacion .gob.ec/wp-content/uploads/downloads/2019/o1/GUIA-METODOLOGICA-EF.pdf

Barseli, M., Sembiring, K., Ifdil, I., \& Fitria, L. (2019). The concept of student interpersonal communication. JPPI (Jurnal Penelitian Pendidikan Indonesia), 4(2), 129. https://doi.org/10.29210/02018259

Basar, A. M. (2021). Problematika Pembelajaran Jarak Jauh Pada Masa Pandemi Covid-19. Edunesia: Jurnal Ilmiah Pendidikan, 2(1), 208-218. https://doi.org/10.51276/edu.v2i1.112

Bismala, L., \& Manurung, Y. H. (2021). Student satisfaction in e-learning along the COVID-19 pandemic with importance performance analysis. International Journal of Evaluation and Research in Education (IJERE), 10(3), 753-759. https://doi.org/10.11591/ijere.v10i3.21467

Creswell, J. W. (2014). Research Design: Qualitative, Quantitative, and Mixed Methods Approaches (4th ed.). SAGE Publications, Inc. http://www.drbrambedkarcollege.ac.in/sites/default/files/Research-Design_QualitativeQuantitative-and-Mixed-Methods-Approaches.pdf

DeVito, J. A. (2013). The Interpersonal Communication Book 13th Edition (13th ed.). Pearson Education, Inc.

Firamadhina, F. I. R., \& Krisnani, H. (2021). Perilaku Generasi Z Terhadap Penggunaan Media Sosial Tiktok: TikTok Sebagai Media Edukasi dan Aktivisme. Journal of Education and Instruction (JOEAI), $10(2), 199$. https://doi.org/10.24198/share.v10i2.31443

Gabatino, B. B., \& Afalla, B. T. (2021). Establishing a nexus between executive functions and management efficacy of academic leaders. International Journal of Evaluation and Research in Education (IJERE), 10 (3), 938-947. https://doi.org/10.11591/ijere.v1oi3.21515

Ghozali, I. (2008). Structural Equation Modeling: Teori, konsep E aplikasi program liserel. Badan Penerbit Undip.

Gunawati, R., Hartati, S., \& Listiara, A. (2006). Hubungan Antara Efektivitas Komunikasi Mahasiswa-Dosen Pembimbing Utama Skripsi Dengan Stres Dalam Menyusun Skripsi Pada Mahasiswa Program Studi Psikologi Fakultas Kedokteran Universitas Diponegoro. Jurnal Psikologi, 3(2), 93-115. https://doi.org/10.14710/jpu.3.2.93

Hadion Wijoyo, Indrawan, I., Cahyono, Y., Handoko, A. L., \& Santamoko, R. (2020). Generasi Z E Revolusi Industri 4.o Penulis (1st ed., Issue July). CV. Pena Persada. https://www.researchgate.net/publication/343416519_GE NERASI_Z_REVOLUSI_INDUSTRI_40

Hair, J. F. J., Black, W. C., Babin, B. J., Anderson, R. E., \& Tatham, R. L. (2006). Multivariate Data Analysis (6th ed.). Pearson Prentice Hall.

Hidayat, D. (2012). Komunikasi Antar Pribadi dan Medianya (Fakta Penelitian Fenomenologi Orang Tua Karir dan Anak Remaja (1st ed.). Graha Ilmu.

Hidayat, D., Anisti, Purwadhi, \& Wibawa, D. (2020). Crisis management and communication experience in education during the covid - 19 pandemic in indonesia. Jurnal Komunikasi: Malaysian Journal of Communication, 36(3), 67-82. https://doi.org/10.17576/JKMJC-2020-3603-05

Mulyono, H., \& Saskia, R. (2021). Affective variables contributing to Indonesian EFL students' willingness to communicate within face-to-face and digital environments. Cogent Education, 8(1). https://doi.org/10.108o/2331186X.2021.1911282

Navarro, O., Sanchez-Verdejo, F. J., Anguita, J. M., \& Gonzalez, A. L. (2020). Motivation of university students towards the use of information and communication technologies and their relation to learning styles. International Journal of Emerging Technologies in Learning, 15(15), 202-218. https://doi.org/10.3991/ijet.v15i15.14347 
Oktary, D., Marjohan, M., \& Syahniar, S. (2019). The Effects of Self-Confidence and Social Support of Parents On Interpersonal Communication of Students. Journal of Educational and Learning Studies, $2(1), 5$. https://doi.org/10.32698/0352

Pavan Kumar, S. (2021). Impact of online learning readiness on students satisfaction in higher educational institutions. Journal of Engineering Education Transformations, 34(Special Issue), 64-70. https://doi.org/10.16920/jeet/2021/v34io/157107

Pearson, J. C., Nelson, P. E., Titsworth, S., \& Harter, L. (2011). Human Communication FOURTH EDITION.

Ramadanty, S., \& Martinus, H. (2016). Organizational Communication: Communication and Motivation in The Workplace. Humaniora, 7(1), 77. https://doi.org/10.21512/humaniora.v7i1.3490

Ridha, M. (2020). Teori Motivasi Mcclelland dan Implikasinya dalam Pembelajaran PAI. Palapa, 8(1), 1-16. https://doi.org/10.36088/palapa.v8i1.673

Rina, N., Suminar, J. R., \& Damayani, N. A. (2019). Patterns of Interpersonal Communication Students Through the Class Tarkiz Quran Memorizers. Ilmu Dakwah: Academic Journal for Homiletic Studies, 13(34), 54-68. https://doi.org/10.15575/idajhs.v12i1.5192

Sadtyadi, H. (2021). Refleksi Kinerja Bidang Pendidikan Dalam Upaya Pelaksanaan Tugas Yang Optimal. In B. S. Wahyu (Ed.), CV Djiwa Amarta (1st ed.). PT Djiwa Amarta.

Samala, A. D., Fajri, B. R., Ranuharja, F., \& Darni, R. (2020). Pembelajaran Blended Learning Bagi Generasi Z Di Era 4.o. Jurnal Teknologi Informasi Dan Pendidikan, 13(1), 45-53. http://tip.ppj.unp.ac.id/index.php/tip/article/view/26o

Sari, Y. N. (2018). The urgency of developing trust and interpersonal communication skills of students through role playing. Konselor, 7(3), 89-94. https://doi.org/10.24036/02018738684-0-oo

Saripudin, S., Sumarto, S., Juanda, E. A., Abdullah, A. G., \& Ana, A. (2020). Vocational school teachers' perceptions of e-learning during covid-19. Journal of Engineering Education Transformations, 34(Special Issue), 7-13. https://doi.org/10.16920/JEET/2020/V34Io/157844

Shaleh, M. (2016). Pengaruh Motivasi, Faktor Keluarga, Lingkungan Kampus Dan Aktif Berorganisasi Terhadap Prestasi Akademik. Phenomenon : Jurnal Pendidikan MIPA, 4(2), 109-141. https://doi.org/10.21580/phen.2014.4.2.122

Shanmugam, K., \& Balakrishnan, B. (2019). Motivation in information communication and technology-based science learning in tamil schools. Jurnal Pendidikan IPA Indonesia, 8(1), 141-152. https://doi.org/10.15294/jpii.v8i1.16564

Siburian, T. A. (2013). The Effect of Interpersonal Communication, Organizational Culture, Job Satisfaction, and Achievement Motivation to Organizational Commitment of State High School Teacher in the District Humbang Hasundutan, North Sumatera, Indonesia. International Journal of Humanities and Social Science, 3(12), 247-264. http://digilib.unimed.ac.id/78o/1/The effect of interpersonal communication $\% 2 \mathrm{C}$ organizational culture $\% 2 \mathrm{C}$ job satisfaction $\%{ }_{2} \mathrm{C}$ and achievement motivation to organizational commitment of state high school teacher in the district humbang hasundutan\% $\%$ C.pdf

Sugiyono. (2003). Metode Penelitian. Alfabeta.

Wahyono, P., Husamah, H., \& Budi, A. S. (2020). Guru profesional di masa pandemi COVID-19: Review implementasi, tantangan, dan solusi pembelajaran daring. Jurnal Pendidikan Profesi Guru, 1(1), 51-65. http://ejournal.umm.ac.id/index.php/jppg/article/view/12462

Weda, S., Atmowardoyo, H., Rahman, F., Said, M. M., \& Sakti, A. E. F. (2021). Factors affecting students' willingness to communicate in EFL classroom at higher institution in indonesia. International Journal of Instruction, 14(2), 719-734. https://doi.org/10.29333/iji.2021.14240a

Wichanpricha, T. (2021). Synchronous online learning through microsoft teams at tertiary level: Academic English course. Journal of Educational and Social Research, 11(5), 123-140. https://doi.org/10.36941/jesr-2021-0111

Wijanto, S. H. (2008). Structural Equation Modeling Dengan Lisrel 8.8. Graha Ilmu. 